\title{
Does the HMF value affect the Antibacterial activity of the Bee Honey?
}

\author{
Emad A. Nafea ${ }^{1}$; Walaa A. Moselhy ${ }^{2}$ and Asmaa, M. Fawzy ${ }^{1}$ \\ 1- Department of Apiculture, Plant Protection Research Institute, Agriculture \\ Research Center, Dokki, Giza, Egypt. \\ 2- Faculty of Science, Zoology Department, Al-Azhar University (Girls)
}

\begin{abstract}
This study evaluated the antimicrobial activity of different levels of HMF value of honey at different concentration (15,20and 25\%honey). Honey and HMF concentrations of $15 \%, 20 \%$ and $25 \%$ honey in distilled water were prepared. These preparations were tested for antimicrobial activity against four different types of pathogenic bacteria; Pseudomonas aeruginosa, Escherichia coli, Staphylococcus aureus and Bacillus subtilis. Antimicrobial activity was determined as an equivalent of the inhibition zones diameters using filter paper discs (in millimeters) after incubation of the cultures at $30^{\circ} \mathrm{C}$ for 24 hours for bacterial species. The results showed a bactericidal activity of HMF value of honey against a broad spectrum of bacteria with variable degrees. By use of least significant differences test for multiple comparisons, it is apparent that the honey of HMF value $(90.24 \mathrm{mg} l \mathrm{~kg})$ showed the highest inhibitory effect on bacterial growth compared to other honey treatments and HMF concentrations. This value $(90.24 \mathrm{mg} / \mathrm{kg})$ had the highest bactericidal activity against Escherichia coli at concentrations of 15and 20\% honey. Similarly, the HMF $(90.24 \mathrm{mg} / \mathrm{kg})$ value had significantly higher inhibitory effects compared to other treatments on Bacillus subtilis growth at concentration 15, 20 and 25\% honey and on Staphylococcus aureus growth at concentration 15and 25\% honey. However, there was no inhibitory effect of HMF value of honey $(203.0 \mathrm{mg} / \mathrm{kg})$ against all bacterial strains tested at concentration $15 \%$ honey. Considerably, no inhibitory effect of all HMF values of honey treatments was noted on Pseudomonas aeruginosa. Conclusion, the different levels of HMF value of honey at different concentration (15,20and 25\%) showed a bactericidal activity against a broad spectrum of bacteria with variable degrees
\end{abstract}

Keywords: Antibacterial, Bee Honey, HMF value

\section{INTRODUCTION}

Honey, as it is found in the hive, is a truly remarkable material elaborated by bees with floral nectar. Nectar is a thin, easily spoiled sweet liquid that is changed ("ripened") by the honeybee to a stable, high density and high energy food. The earlier US Food and Drug Act defined honey as " the nectar and saccharine exudation of plants, gathered, modified and stored in the comb by honey bees (Apis mellifera and A. dorsats). The limits established in this definition were largely based on a survey published in 1908. Today, this definition has an advisory status only, but is not totally correct, as it allows too high a content of water and sucrose and too low in ash (Molan, 1992).

Honey has been used as a medicine since ancient times in many cultures. Actually honeys vary according to their plant origin and the conditions of their production (Bogdanov,1997) .The use of honey as therapeutic substance has been 
rediscovered by the medical profession in more recent times and its gaining acceptance as an antibacterial agent for the treatment of some diseases (Efen,1988)

Honey has antimicrobial properties that discourage the growth or persistence of many microorganisms. The microbes that may be found in honey are primarily yeasts and spore-forming bacteria. The medicinal properties of honey has been reported and documented by beekeepers and medical practitioners alike (Molan, 1992 and Bankova et al., 2000). Several studies have been conducted to authenticate this 'forklore' on medicinal properties of honey and there has been a renaissance in the use of honey as medicine in more recent times (Molan, 1992 Bogdanov, 1997, Zumla and Lulat 1989 and Fearnley, 2001). The use of alternative therapies is mostly due to development of antibiotic resistance in bacteria and/or increasing awareness on the adverse side effects of many pharmaceuticals (Fearnley, 2001).

Hydroxymethylfurfural, also called HMF, is a compound that results from the breakdown of simple sugars (such as fructose) at $\mathrm{pH} 5$ or lower. HMF occurs naturally in honey, especially in warm climates.

HMF (5-hydroxymethylfurfuraldehyde) measurement is used to evaluate the quality of honey; generally not present in fresh honey, its content increases during conditioning and storage. Honey processing, requires heating both to reduce viscosity, and to prevent crystallization or fermentation (Singh, Singh, Bawa, \& Sekhon, 1988) in air ventilated chambers, at $45-50^{\circ} \mathrm{C}$ for $4 / 7$ days or by immersion of honey drums in hot water. Heating of unifloral honey leads to different HMF levels in honey (Fallico, Zappal_a, Arena, \& Verzera, 2004). HMF is formed during acid-catalysed dehydration of hexoses and, it is connected to the chemical properties of honey, like pH, total acidity and mineral content (Anam \& Dart, 1995; Bath \& Singh, 1999; Hase, Suzuki, Odate, \& Suzuki, 1973; Singh \& Bath, 1997, 1998).

Codex Alimentarius (Alinorm 01/25 2000) established that the HMF content of honey after processing and/or blending must not be higher than $80 \mathrm{mg} / \mathrm{kg}$. The European Union (EU Directive 110/2001) fixed a HMF limit in honey of $40 \mathrm{mg} / \mathrm{kg}$ with the following exceptions: $80 \mathrm{mg} / \mathrm{kg}$ for honey coming from Countries or Regions with tropical temperatures.

However, it is obvious that being able to enter other reactions, this highly reactive compound can make the nutritional value of honey lower by the degradation of its unstable components, or possibly affect its colour if present in higher concentrations (Surh et al., 1994; Kubiš and Ingr, 1998; Gangolli, 1999; Janzowski et al., 2000).

Considering all the facts mentioned above, the content of HMF is an important parameter in the evaluation of honey quality. It also enables to detect the damage of honey or its adulteration by invert sugar or starch syrup (Kubiš and Ingr, 1998; Wunderlin et al., 1998; Nozal et al., 2000).

This work was conducted in the year (2010), at Beekeeping Research Department , Plant Protection Research Institute, ARC, Giza , Egypt and Faculty of Science, AlAzhar University.

The present work had an aim; it was to detect which level of HMF value of honey had a potential effect on bacteria.

\section{MATERIALS AND METHODS}

\section{Honey preparation}

The honey solution was prepared by mixing honey in pure form to sterilized distilled water at various concentrations of 15,20 and $25 \%$. 
The Hydroxymethylfurfural (5-hydroxymethyl-2 furalde-hyde) (HMF) of old honey were analyzed at the Chemical Analysis Laboratory of Honeybee Products, at Beekeeping Research Department, Plant Protection Research Institute, ARC, Giza, Egypt.

\section{Determination of Hydroxymethylfurfural (HMF)}

It was determined according to Winkler (1955) as following, the reagents:

Barbituric acid solution: $500 \mathrm{mg}$ barbituric acid was transferred to $100 \mathrm{ml}$ graduated flask using $70 \mathrm{ml}$ water. Then the flask placed in a hot water-bath until all amount of barbituric acid was dissolved, cool and make up to volume.

P-toluidin solution: Weight out $10 \mathrm{~g}$ P-toluidin, analytical grade, and dissolved in about $50 \mathrm{ml}$ isopropanol by gentle warming in a water-bath then, transfer to a 100 $\mathrm{ml}$ graduated flask with isopropanol and add $10 \mathrm{ml}$ glacial acetic acid. Cool and make up to volume with isopropanol. Keep solution in the dark. Don't use for at least 24 hours.

Distilled water (oxygen free): Nitrogen gas was passed through boiling distilled water. Then water is cooled.

Procedure.

1. Preparation of test sample.

$5 \mathrm{~g}$ of honey sample is weighted and dissolved without heating with oxygen free distilled water and transferred to a $25 \mathrm{ml}$ graduated flask and made up to volume (honey solution). The sample should be tested after preparation without delay.

2. Photometric determination.

$2.0 \mathrm{ml}$ of honey solution is pipette into each of two test tubes and $5.0 \mathrm{ml} \mathrm{P}$ toluidine solution is added to each. Into one test tube $1 \mathrm{ml}$ water is pipette and into the other $1 \mathrm{ml}$ barbituric acid solution and both mixtures are shaken. The tube with added water, serves as the water blank. The addition of reagents should be done without pause and should be finished in about 1-2 min. The extinction of the sample is read against the blank at $550 \mathrm{~nm}$ using a $1-\mathrm{cm}$ cell, immediately the maximum value is reached.

3. Calculation and expression of results:

The method may be calibrated by using a standard of HMF standardized by dissolving commercial or laboratory prepared HMF and assying spectrophotometrically. The equation by which results may be roughly worked out is $\mathrm{mg} / 1000 \mathrm{~g} \mathrm{HMF}=$ absorbance $/$ thickness of layer $* 192$. Results are expressed as $\mathrm{mg} \mathrm{HMF/Kg} \mathrm{honey.}$

The antibacterial effects of honey were tested on gram positive (Staphylococcus aureus, and Bacillus subtilis) and gram negative Pseudomonas aeruginosa, and Echerichia coli bacteria. .

\section{Assay of Antibacterial Activity}

The antibacterial activity of honeys was measured using a classical diffusion method. In general, this method is based on the observation of inhibition of microbial growth on agarized media (Shimanuki and Knox, 1991).

\section{The medium used for bioassay test:}

Nutrient agar medium consisted of $(\mathrm{g} / \mathrm{L})$ peptone, 5.0; beef extract, 3.0; $\mathrm{NaCl}$, 5.0 and agar-agar, 15.0. The $\mathrm{pH}$ was adjusted to 7.0.

\section{Procedure}

1- Twenty four hours old culture of each of the test microbial strains was used.

2- Five $\mathrm{ml}$ of sterile distilled water were added to the culture tube and mixed by a vortex mixer. 
3- Five drops of the suspension were added to $100 \mathrm{ml}$ of nutrient agar medium at $45^{\circ} \mathrm{C}$. This was dispensed among Petri dishes, $10 \mathrm{ml}$ for each.

4- Three concentrations (15,20and $25 \%$ ) of each honey with different HMF values in distilled water were prepared in clean sterile test tubes.

5- Analytical paper disks 740-E/2 "Diam" were loaded with the honey and aseptically put on the surface of the seeded plates with the two different test organisms.

6- The plates were left for 2 hours in a refrigerator for diffusion after which the plates were incubated at $30^{\circ} \mathrm{C}$ for 24 hours.

The diameter of a clear zone around the paper disks was an indication of the antagonistic properties of the honey under study and measured in $(\mathrm{mm})$

\section{Statistical Analysis}

Results were analyzed using Analysis of Variance (ANOVA) with the probability $\mathrm{p}=0.05$ as the critical value for all test. LSD test was used for separation of statistically significant means.

\section{RESULTS AND DISCUSSION}

The different level of HMF value of honey at different concentration $(15,20$ and $25 \%$ ) showed a bactericidal activity against a broad spectrum of bacteria with variable degrees, Table (1). By use of least significant differences (LSD) test for multiple comparisons, it is apparent that the HMF value of honey $(90.24 \mathrm{mglkg})$ showed the highest inhibitory effect on bacterial growth compared to other honey treatments and concentrations. This value $(90.24 \mathrm{mg} / \mathrm{kg})$ was the highest bactericidal activity against E.coli at concentration of 15 and $20 \%$ honey $(\mathrm{P}=0.000, \mathrm{~F}=5190.03, \mathrm{LSD}=0.215)$. Similarly, the HMF $(90.24 \mathrm{mg} / \mathrm{kg})$ value had significantly higher inhibitory effects compared to other treatments on B. subtilis growth at concentrations 15,20 and $25 \%$ honey $(\mathrm{P}=0.000, \mathrm{~F}=5597.46, \mathrm{LSD}=0.205)$, and had significantly higher bactericidal activity against $S$. aureus at concentrations 15 and $25 \%$ honey compared to other treatments $(\mathrm{P}=0.000, \mathrm{~F}=5862.32, \mathrm{LSD}=0.219)$. However, there was no inhibitory effect of HMF value of honey $(203.0 \mathrm{mg} / \mathrm{kg})$ against all bacterial strains tested at concentration $15 \%$ honey. Considerable, no inhibitory effect of all HMF value of honey treatment was noted on $P$. aeruginosa.

Table 1: Summary of the antimicrobial activity of varying concentrations of HMF of honey against 4 bacteria strains (, S. aureus, B. subtilis, P. aeruginosa and E.coli).

\begin{tabular}{|c|c|c|c|c|c|c|c|c|c|c|c|c|c|c|c|c|c|c|}
\hline \multirow{3}{*}{$\begin{array}{l}\text { Bacteria } \\
\text { strains }\end{array}$} & \multicolumn{3}{|c|}{$\begin{array}{c}\text { Control } \\
(\text { HMF5.0 mg/kg ) } \\
\end{array}$} & \multicolumn{3}{|c|}{$\begin{array}{c}\text { HMF } \\
(76.8 \mathrm{mg} / \mathrm{kg}) \\
\end{array}$} & \multicolumn{3}{|c|}{$\begin{array}{c}\text { HMF } \\
(90.24 \mathrm{mg} / \mathrm{kg})\end{array}$} & \multicolumn{3}{|c|}{$\begin{array}{c}\text { HMF } \\
(138.0 \mathrm{mg} / \mathrm{kg})\end{array}$} & \multicolumn{3}{|c|}{$\begin{array}{c}\text { HMF } \\
(203.0 \mathrm{mg} / \mathrm{kg})\end{array}$} & \multicolumn{3}{|c|}{$\begin{array}{c}\text { HMF } \\
(288.0 \mathrm{mg} / \mathrm{kg}) \\
\end{array}$} \\
\hline & \multicolumn{18}{|c|}{ Honey concentration } \\
\hline & $15 \%$ & $20 \%$ & $25 \%$ & $15 \%$ & $20 \%$ & $25 \%$ & $15 \%$ & $20 \%$ & $25 \%$ & $15 \%$ & $20 \%$ & $25 \%$ & $15 \%$ & $20 \%$ & $25 \%$ & $15 \%$ & $20 \%$ & $25 \%$ \\
\hline $\begin{array}{l}\text { Staphylococcus } \\
\text { aureus }\end{array}$ & 9.1 & 12.13 & 16.1 & 10.13 & 16.1 & 20.13 & 13.1 & 18.16 & 22.1 & 9.1 & 14.13 & 20.13 & $\mathrm{Na}$ & 10.16 & 4.16 & 6.16 & 11.13 & 16.16 \\
\hline $\begin{array}{l}\text { Bacillus } \\
\text { subtilis }\end{array}$ & 8.1 & 12.13 & 14 & 8.1 & 13.1 & 18.16 & 12.13 & 17.13 & 21.16 & 16.13 & 8.1 & 15.1 & $\mathrm{Na}$ & 5.1 & 14.1 & 15.13 & 8.1 & 13.16 \\
\hline $\begin{array}{l}\text { Pseudomonas } \\
\text { aeruginosa }\end{array}$ & $\mathrm{Na}$ & $\mathrm{Na}$ & $\mathrm{Na}$ & $\mathrm{Na}$ & $\mathrm{Na}$ & $\mathrm{Na}$ & $\mathrm{Na}$ & $\mathrm{Na}$ & $\mathrm{Na}$ & $\mathrm{Na}$ & $\mathrm{Na}$ & $\mathrm{Na}$ & $\mathrm{Na}$ & $\mathrm{Na}$ & $\mathrm{Na}$ & $\mathrm{Na}$ & $\mathrm{Na}$ & $\mathrm{Na}$ \\
\hline Echerichia coli & 7.1 & 12.13 & 15.16 & 12.13 & 14.1 & 16.16 & 12.13 & 14.1 & 19.1 & 4.13 & 6.1 & 17.16 & $\mathrm{Na}$ & 4.16 & 12.1 & 3.16 & 7.1 & 10.16 \\
\hline Stap & & 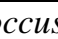 & 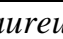 & $\mathrm{P}=$ & $\overline{00}$ & $=5$ & 32 & $\overline{\mathrm{LS}}$ & .21 & & & & & & & & & \\
\hline $\begin{array}{l}B a c \\
E c h\end{array}$ & $\begin{array}{l}\text { us } \\
\text { ich }\end{array}$ & $\begin{array}{l}\text { colil } \\
\text { cotion }\end{array}$ & & $\begin{array}{l}\mathrm{P}=0 \\
\mathrm{P}=0\end{array}$ & $\begin{array}{l}000 ; \\
000 ;\end{array}$ & $\begin{array}{l}=55 \\
=51\end{array}$ & $\begin{array}{l}7.46 \\
.03\end{array}$ & $\begin{array}{l}\text {; LSD } \\
\text { LSD }\end{array}$ & $\begin{array}{c}=0.2 \\
0.21\end{array}$ & & & & & & & & & \\
\hline
\end{tabular}

Mixed observations were made regarding the susceptibility of the test microbes to the honey with high value of HMF. B. subtilis, E.coli and S. aureus were susceptible to all HMF value of honey treatments. All HMF values of honey 
treatments and concentrations of honey did not inhibit the growth of $P$. aeruginosa. (Demera and Angert, 2004) reported that S. aureus was susceptible to honey from Apis mellifera and the stingless bee Tetragonisca angustula. (Efem, 1993) and (Radwan, et al. 1984) also reported that honey from A. mellifera inhibits the growth E. coli. Mercan ${ }^{\mathrm{a}}$ et al. (2007) studied the antibacterial activity of honey samples from different sources against Bacillus cereus, Staphylococcus aureus, Pseudomonas aeruginosa and Escherichia coli .The results showed that majority of the honey samples $(75 \%)$ generally inhibited the bacteria tested. The honey samples which were obtained from Zmir showed more effectiveness as inhibitors against $P$. aeruginosa, $E$. coli, and S. aureus. Tharwat and Danial (2007) suggested that most samples of stored honey inhibited the growth of many of the tested microbial species indicating the less importance of diastase activity, HMF content and $\mathrm{pH}$ of honey.

Collectively, our findings indicate that the different levels of HMF value of honey at different concentrations (15,20and 25\%) showed a bactericidal activity against a broad spectrum of bacteria with variable degrees.

\section{REFERENCES}

Anam, O. O. and Dart, R. K. (1995). Influence of metal ions on hydroxymethylfurfural formation in honey. Analytical Proceedings Including Analytical Communications, 32: 515-517.

Anand, S. and Shanmugam J. (1998).Anti-staphylococcal properties of natural Honey.Biomedicine 18: $15-18$.

Bankova, V.; Marcucci M C. and Catro S. L. (2000). Propolis: recent advances in chemistry and plant origin. Apidologie 31: 3-15.

Bath, P. K. and Singh, N. (1999). A comparison between Helianthus annuus and Eucalyptus lanceolatus honey. Food Chemistry, 67: 389-397.

Bogdanov, S. (1997). Nature and origin of the antibacterial substances in honey. Lebensmittal Wissenschaft and Technology. 30(7): 748-753.

Codex Alimentarius, Alinorm 01/25 (2000). Draft revised standard for honey at step 8 of the Codex procedure.

Demera, J. H. and Angert, E. R. (2004). Comparison of the antimicrobial activity of honey produced by Tetragonisca angustula (Meliponinae) and Apis mellifera from different phytogeographic regions of Costa Rica. Apidologie 35: 411-417.

Efem S. E. (1988). Clinical observations on the wound healing properties of honey. $\mathrm{Br}$ J Surg. 1988 Jul; 75(7):679-81.

Efem, S. E. (1993). Recent advances in the management of fournier's gangrene: Preliminary observations: Surgery 113: 200 - 204.

EU Directive /110/2001 of 02/12/2001 (L 10/47).

Fallico, B.; Zappal_a, M., Arena, E., and Verzera, A. (2004). Effects of heating process on chemical composition and HMF levels inSicilian monofloral honeys. Food Chemistry, 85: 305-313.

Fearnley J. (2001). Bee Propolis: Natural Healing from the Hive. Souvenir Press Ltd.Great Russell Street, London WC1B 3PD: 24-59

Gangolli S. (ed.) (1999). Dictionary of Substances and their Effects. The Royal Society of Chemistry, Cambridge.

Hase, S.; Suzuki, O.; Odate, M. and Suzuki, S. (1973). Changes in quality of honey on heating and storage. I. Changes in hydroxymethylfurfural (HMF) content of honey. Journal of Food Science and Technology, 20: 248-256 
Janzowski C.; Glaab V.; Samimi E.; Schlatter J. and Eisenbrand G. (2000). 5hydroxymethylfurfural: assessment of mutagenicity, DNA-damaging potential and reactivity towards cellular glutathione. Food Chem. Toxicol., 38: 801-809.

Kubiš I. and Ingr I. (1998). Effects inducing changes in hydroxymethylfurfural content in honey (in Czech). Czech J. Anim. Sci., 43, 379-38

Molan, P. C.(1992). The antibacterial activity of honey 1. The nature of the antibacterial activity Bee world 73(1): 5-28.

Nazime Mercan; Aykut Guvensen; Ali Celik; Hikmet Katircioglu (2007) Antimicrobial activity and pollen composition of honey samples collected from different provinces in Turkey J. Natural Product Research, 21(3): $187-195$.

Nozal M.J.; Bernal J.L.; Toribio L.; Jiménez J.J. and Martín M.T. (2001). Highperformance liquid chromatographic determination of methyl anthranilate, hydroxymethylfurfural and related compounds in honey. J. Chromatogr. A, 917: 95-103.

Shimanuki H. and Knox D.A. (1991). Diagnosis of honey bee diseases. US Department of Agriculture, Agriculture Handbook No. AH- 90, 53 p. A revised edition of this publication was issued in 2000.

Singh, N.; Singh, S.; Bawa, A. S. and Sekhon, K. S. (1988). Honey-its food uses. Indian Food Packer, 42: 15-25.

Singh, N. and Bath, P. K. (1997). Quality evaluation of different types of Indian honey. Food Chemistry, 58: 129-133.

Singh, N. and Bath, P. K. (1998). Relationship between heating \& hydroxymethylfurfural formation in different honey types. Journal of Food Science and Technology, 35: 154-156.

Surh, Y.J.; Liem, A..; Miller, J.A. and Tannenbaum, S. R. (1994). 5sulfooxymethylfurfural as a possible ultimate mutagenic and carcinogenic metabolite of the Maillard reaction-product, 5-hydroxymethylfurfural. Carcinogenesis, 15: 2375-2377.

Radwan, S.; El-Essawy, A. and Sarhan, M. M. (1984). Experimental evidence for the occurrence in honey of specific substances active against microorganisms. Zentral Mikrobiol 139: 249 - 55

Tharwat, E. E. and Danial Enas N.(2007). Effect of bee honey .storage on diastase activity, hydroxymethylfurfural content, $\mathrm{pH}$ and antimicrobial activity. Egypt. J. of Appl. Sci, 22(6B) 2007 766-773

Winkler, O. (1955). Beitrag zum Nachweis und zur Bestinunung von Oxymethylufural in Honig und Kunsthonig z. Lebensmittelunters. u. Porsch, 102:161-167.

Wunderlin, D.A.; Pesce, S. F.; Amé, M.V. and Faye, P. F. (1998): Decomposition of hydroxymethylfurfural in solution and protective effect of fructose. J. Agr. Food Chem., 46:1855-1863.

Zumla, A. and Lulat, A. (1989). Honey - a remedy rediscovered. Journ. of Royal Soc. of Medicine 82: $384-385$. 


\section{ARABIC SUMMARY}

هل يوجد تأثير لقيم هيدركسى ميثايل فورفورال (HMF ) على نشاط عسل النحل كمضاد بكتيرى؟

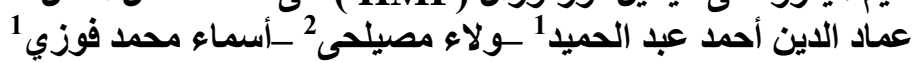

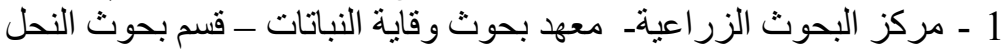
2 - كلية العلوم - قسم علوم الحيو انـ- جامعة الأز هر(بنات)

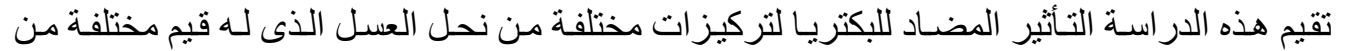

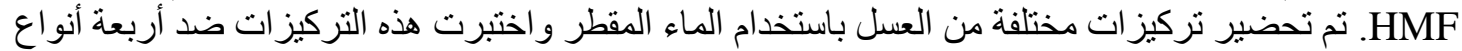

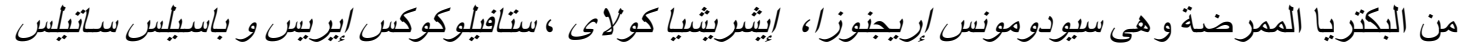

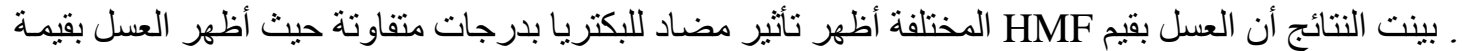

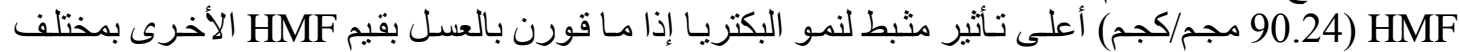

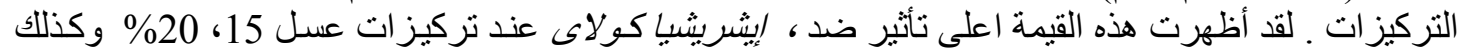

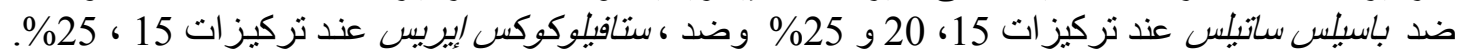

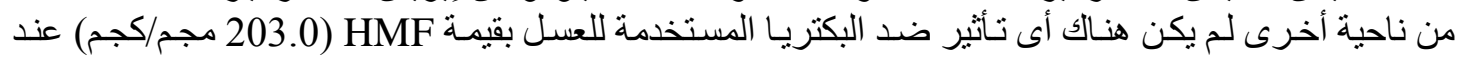
تركيز 15\% بينما لم تتأثر بكترياسيودومونس إريجنوز البأى من التركيز ات المختلفة لقيم HMF المستخدمة 